\title{
A Corpus-based Study of Gender Representation in ELE Textbooks — Language, Illustrations and Topic Areas
}

\author{
Johanna Lea Korell \\ Justus Liebig University, Germany
}

\begin{abstract}
In the following article, gender-related aspects in ELE textbooks will be examined from a broader thematic point of view, as well as detailed linguistic perspective. As a starting point, the state of research on gender-related studies in foreign language teaching pedagogy and research in Germany will be outlined, followed by a discussion on the importance of gender awareness promoting textbooks. After a general introduction and a rationale for the relevance of the study, central findings of studies examining gender representation in ELE textbooks will be discussed. This is followed by an analysis, in which specifics of textbook analysis and sampling criteria are explained. Furthermore, an analysis model is developed, based on the latest findings of gender-related textbook research. After an excursus on language-specific possibilities of gender sensitivity in Spanish, the results of the analysis are presented and discussed. Finally, implications of the findings for teachers will be deduced and recommendations regarding what can be done to promote and deepen gender awareness of learners will be given.
\end{abstract}

Index Terms—ELE textbook, gender, language, illustrations, topic areas, Germany

\section{INTRODUCTION AND RELEVANCE OF THE STUDY}

Although gender theoretical approaches play an ever increasing role in almost all scientific disciplines and research areas (e.g. humanities, social and cultural sciences, law, economics, medicine), they are not the focus of the foreign language teaching pedagogy and research in Germany (Babka/Posselt 2016; Elsner/Lohe 2016, 9; Gutenberg 2013).

Nevertheless, the increased attention to the topic gender in the foreign language teaching research can be seen in several publications in the shape of anthologies (Decke-Cornill/Volkmann 2007; Elsner/Lohe 2016), handbook entries (Schmenk 2016/2019), articles (Elsen 2018; Gutenberg 2013; König 2015; Linke 2012; Mittag 2015; articles of the aboved-mentioned anthologies), special issues in journals (Der fremdsprachliche Unterricht Englisch 2015; Praxis Fremdsprachenunterricht 2009), monographs (König 2018; Schmenk 2002) or conferences (Free University of Berlin 2020; Friedrich-Schiller University of Jena 2006; Goethe University of Frankfurt 2018). Even if only a few publications related to gender are counted in the field of research into Spanish as a foreign language (ELE) an intensified interest in the topic can be observed (Grein 2012; Grünewald/Küster 2017; Koch 2020; Lüning/Vences 2007).

In general, it has become accepted that gender can be seen as a fundamental factor in how societies organise the social life of people, how one experiences, describes and evaluates the social world, and how individuals perceive themselves in their relationship to others. Despite their diversity, their different methods and cognitive interests, the different approaches largely agree that the category gender cannot be seen as given, but rather represents a complex construction that influences our self-image and our ideas of gender and gender relations as well as our sexuality (Babka/Posselt 2016).

Since the 1990s, gender issues are no longer just a component of other research disciplines, but have become one of its own. The Gender-Studies "deal with the analysis and criticism of asymmetrical gender relations" (Schößler, 2008, 9), which "differentiate between gender as a social construct that is formed by discursive practices and negotiations; and the biological sex" (Elsner/Lohe, 2016, p. 9). Gender includes "a person's gender identity (defining oneself as man, woman, genderqueer), gender expression (expressing masculinity and/or femininity), attraction (sexual/romantic/asexual) and the biological sex" (König/Surkamp/Decke-Cornill, 2015, p. 6).

In both the public and private sector, society is confronted with gender issues and social concepts (König/Lewin/Surkamp 2016). Particularly the school is an institution, in which socially shared cultural knowledge is conveyed, such as social norms and values or stereotypes about different social groups ( Moser/Hannover/Becker 2013). Nevertheless, school lessons also "offer the chance to make limiting concepts of gender and sexuality a topic, to encourage a critical discussion of gender-related norms and exclusions, and to open new perspectives" (König/Lewin/Surkamp, 2016, p. 21).

Foreign language teaching is particularly suitable for gender thematization and reflection, since it is intended to encourage pupils to engage with 'foreign' cultures, identities and perspectives and to open up new perspectives on their own world. This makes it an excellent opportunity for critical reflection on gender as a dominant category, structuring society to a high degree and creating identity (Lewin 2015). 
In addition to this, the curricula of most of Germany's federal states include gender-related topics (equality, equal rights, sexual education, sexual self-determination). For modern foreign language teaching, the ability to communicate about sexuality is specifically mentioned. It is precisely the highlighting of linguistic aspects that allows crossconnections to foreign language teaching (e.g. Berliner Rahmenlehrplan).

Considering the structure and content of foreign language lessons in the language acquisition phase, materials in general and textbooks in particular are of certain importance, because they do not only serve to instruct learners in their subject matter (Moser/Hannover/Becker 2013), they "contribute to constructing new knowledge and behavioural modes" (Benitt/Kurtz, 2016, p. 171), which leads to the assumption that materials and media can have an impact on the learners' perspective, expectations and patterns of behaviour and interpretation related to gender (ibid.).

In this respect, access via the foreign language has an advantage. Although the foreign language slows down negotiations on gender and reduces their complexity, it also offers a certain "space of protection and distance" (DeckeCornill, 2009, p. 14). Especially topics and terms that are emotionally charged, tabooed or otherwise particularly normatively charged are easier to negotiate in a language in which the linguistic form of expression is not yet so closely linked to the cultural meaning (König 2015).

Furthermore the inclusion of learners from many nationalities, socio-economic backgrounds and genders has become a core topic of pedagogical and didactic theory, research and practice (Elsner/Lohe 2016), the institutional strengthening of ELE, especially as the second foreign language at German secondary schools (Bär 2012; Statistisches Bundesamt 2018) and the lack of publications relating the topic gender to the field of teaching and learning ELE (Grein 2012; Sunderland 2010) lead to this particular relevance and interest to investigate how gender is represented in ELE textbooks.

\section{GENDER AS AN OBJECT OF INVESTIGATION IN ELE TEXTBOOK RESEARCH IN NATIONAL AND INTERNATIONAL CONTEXTS}

As stated above, gender topics cannot be characterised as a central topic of foreign language and (ELE) textbook research in Germany, which is why a brief reference to general textbook research related to gender issues for contextualization purposes precedes the further explanations.

The study of gender in textbooks begins in the late 1970s, based on the women's studies that have emerged from the second West German women's movement and leads to a phase of politically motivated textbook research. With the further development of women's studies, the categories of analysis used in textbook studies are changing. In the 1970/80s the focus tends to be on sexism and gender, whereas more recent studies refer primarily to sexual identity, heteronormativity or social inequalities. There is still little research on the representation of Lesbian, Gay, Bisexual and Transgender (LBGT) in textbooks (Bittner 2015).

Subsequently, different lines of research that deal with gender issues in teaching and learning foreign languages will be presented (Benitt/Kurtz, 2016, p. 170; Sunderland, 2010, p. 4):

- "Gender differences in language learning and gender-specific approaches to teaching foreign languages" (Klieme 2006)

- "Reasons for gender differences in the overall performance of language learners" (Schmenk 2002)

- "Teaching gender explicitly [...] in the foreign language classroom" (König/Surkamp/Decke-Cornill 2015)

- "The role of gender in instructional materials" (Benitt/Kurtz 2016; Bittner 2011; Elsen 2018; Ott 2017)

The latter area particularly addresses the question of how gender is represented in materials, for instance the equal and realistic representation of men and women (Sunderland 2010).

Gender-related issues have not played a major role in (ELE) textbook research both in national and international contexts (Bengoechea/Simón 2010; Benitt/Kurtz 2016; Sunderland 2010). Sunderland (2010) even explicitly emphasises that there is a particular lack of gender research in foreign language contexts in which English is not the target language (p. 5).

Since no ELE textbook analysis of gender-related aspects can be found in the German research context, only analyses of the international research context are presented.

It should be noted that these results are only partially relevant for the present analysis, as they are embedded in different national and educational contexts. The following ELE textbook analyses, which examine gender-related aspects, can therefore be presented in chronological order:

- $\quad$ sexist representation in ELE textbooks (Galiano Sierra 1993)

- $\quad$ occurrence of men and (famous) women in illustrations in ELE textbooks between 1991 and 2005 (Robles Fernández 2005)

- $\quad$ verbal and graphic representation of men and women in ELE textbooks (2003-2004) for beginners (Barceló Morte 2006)

- $\quad$ representation of women in Spanish Second Language textbooks (Robles Fernández 2007)

- role and social consideration of women and minorities in ELE textbooks in the 1980s (1980-1994) (de Santiago Guervós 2009)

- language, job titles, professional identity in 60 ELE textbooks published after 1999 (Bengoechea/Simón 2010) 
- i.a. gender roles and LGBTIQ+ identities in five ELE textbooks published after 2009 (Morales-Vidal/Cassany 2020)

After reviewing the preceding analyses, one will see that the object of investigation is often considered from a binary gender perspective and language itself is less frequently examined. The results of the above analyses show that there is a stereotypical approach to the issue of gender. Men and women are not portrayed equally and with different characteristics. Almost all textbooks use the generic masculine without exception and do not differentiate. It is noticeable that hardly any gender-sensitive language is used. Furthermore, male occupations are not only presented more often, but also have priority over female occupations.

At this point it is important to include the analyses of foreign-language textbooks (e.g. English) in the German research context, which already contain further differentiated focal points (e.g. language, homosexuality, LSBTI) (Benitt/Kurtz 2016; Bittner 2011; Elsen 2018). In this respect, the present analysis will now take a closer quantitative and qualitative look at language, illustrations, topic areas and the representation of (non-)binary gender constructions in ELE textbooks.

\section{GENDER-RELATED ASPECTS IN ELE TEXTBOOKS}

\section{A. Introductory Notes and Specifics of Textbook Analyses}

Before sampling and analysis criteria as well as central findings are presented, the characteristics of textbook analyses in general should precede for the purpose of contextualising the present results.

Textbooks as materials specially produced for educational contexts are subject to regulatory framework, such as school laws, guidelines on sex education, educational standards, curricula, and admission requirements.

Furthermore, economic conditions within the German textbook market (16 regional markets), need to be pointed out, which are fundamentally shaped by the structures of education systems, curricular developments, demographic trends and the country-specific systems of financing learning materials (Bittner 2015).

Notwithstanding the content, the material-inherent limitations should be considered, as "classroom materials alone are always mediated by what is done with them, how they are consumed by the teacher and learners" (Sunderland, 2010 , p. 4). The quotation shows the significance of the interaction between teacher/learner and material to realise the full potential by using them critically, creatively and flexibly. Therefore, the results of any textbook analysis should be considered against this background.

\section{B. Sampling Criteria}

The selection of ELE textbooks is based on the following dimensions of corpus compilation:

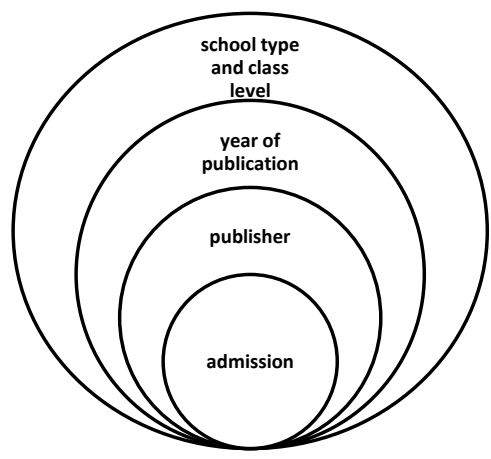

In total, five textbooks for Spanish as the second foreign language at secondary schools (secondary level I) in Germany were analysed. For this purpose, ELE textbooks were selected that can be assigned to the modern generation of textbooks and were published for a period from 2012 to 2019.

For each of the class levels examined (first/second and fourth year of learning), several textbooks were selected, which are frequently used.

As a result, a panoramic view over different class levels at secondary level I can be shown on the one hand, and a certain depth in one class level on the other hand can be seen.

This will give an impression of whether and how ELE textbooks change with the increasing class level respective to gender-related aspects.

In addition, textbooks from various publishing houses were selected, which do not only refer to the leading publishing houses in Germany. Overall, textbooks from the following publishers were analysed: C.C. Buchner, Cornelsen, Klett (Difusión), Schöningh.

Furthermore, each of the textbooks is approved in several German states and was published after the adoption of the Federal Equality Act (BGleiG 2001).

Based on the preceding explanations, the following ELE textbooks were chosen:

- $\quad$ iArriba! 1 (2015), 1st edition. Bamberg: C.C. Buchner. 
- Rutas para ti (2012), 1st edition. Paderborn: Schöningh.

- ¡Vamos! ¡Adelante! 2 (2015), 1st edition. Stuttgart: Klett.

- $\quad$ iApúntate! 4 (2019), new edition. Berlin: Cornelsen.

- Gente Joven 4 (2016), new edition. Stuttgart/Barcelona: Klett/Difusión

Finally, it should be noted that the data presented are neither complete nor representative of all modern ELE textbooks for lower and upper secondary education published in Germany.

\section{Analysis Criteria}

The criteria on which the present analysis is based tie in with already existing analysis models and evaluation instruments (Moser/Hannover/Becker 2013; Nova Scotia Department of Education 2001; Ott 2017). In view of the primary interest of the study, analysis levels and dimensions were adapted to the object of investigation and priorities were set (e.g. consideration of non-binary gender identities).

With the present analysis grid, a comprehensive view of dealing with gender-related aspects in tasks, texts, illustrations and vocabulary can be realised, since both the level of language and the presentation of gender-related topics themselves are at the centre of the investigation and can be networked with each other.

Thus, the ELE textbooks were examined according to the following levels and dimensions:

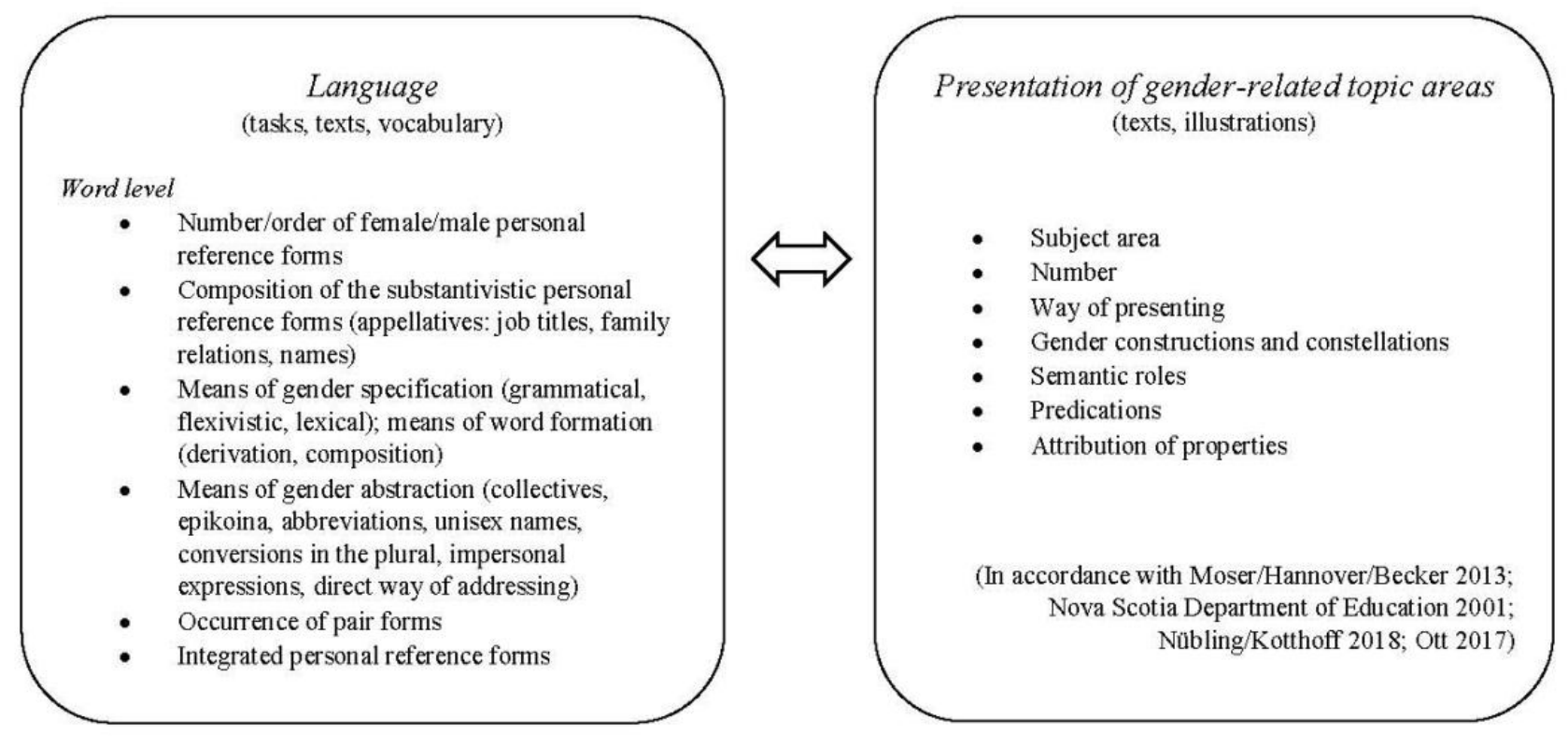

The dimensions mentioned above are subjected to a quantitative and qualitative examination. By analysing the object of investigation from these two perspectives, more extensive results can be derived.

For example, it can be investigated whether and how the generic masculine or other possibilities (methods of gender specification/abstraction) are used. There are various possibilities, e.g. using the generic masculine to designate male persons, persons of unknown or unspecific gender, mixed-gender groups and generally human beings, which can lead to the fact that recipients cannot tell from a text whether it is a gender-specific masculine or a generic use (Moser/Hannover/Becker 2013).

A further linguistic mechanism for establishing gender (in)justice is systematic differences in the first and subsequent naming of male and female persons. Hegarty et al. (2011) have shown that male first names are mentioned significantly more often before female first names than vice versa. Several studies have shown that girls and/or women are more likely to be (mentally) associated with the given subject when gender-equitable language is used in the corresponding texts compared to those texts without gender-equitable language (e.g. Garnham et al. 2012).

This scientific finding has led to the introduction of guidelines for gender-appropriate language use in various countries and universities (Moser/Hannover/Becker 2013). However, there are no guidelines for textbook publishers (cf. Linke 2012, 162), but there are a lot of instructions in Spanish for the use of neutral language ( Guías Para El Uso No Sexista Del Lenguaje (Spain), Guía de Lenguaje Inclusivo de Género (2016, Chile), Lenguaje Inclusivo En Cuanto Al Género (United Nations)).

The use of masculine forms such as 'he' in a generic sense and the problem of pronouns in general, titles and salutations, order, parallel or neutral job titles and much more emerged as critical issues.

Therefore, a selection of possibilities of a gender-neutral Spanish language will be briefly illustrated in the form of an excursus to be able to contextualise the findings presented later: 


\begin{tabular}{|c|c|}
\hline Less gender-sensitive language & Gender-sensitive language \\
\hline 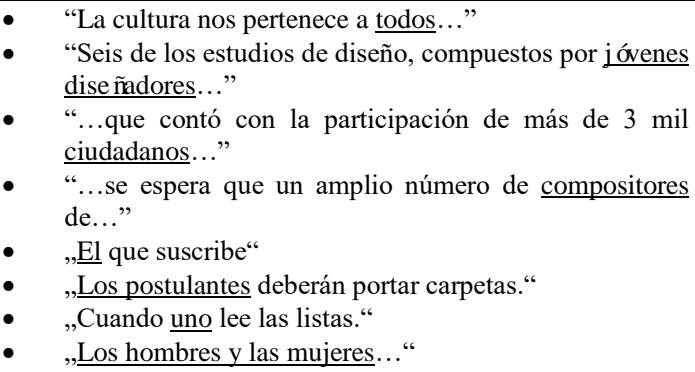 & $\begin{array}{l}\text { - "La cultura le pertenece a toda la ciudadanía...” } \\
\text { - "Seis de los estudios de diseño, compuestos por jóvenes } \\
\text { diseñadoras y diseñadores..." } \\
\text { " “...que contó con la participación de más de } 3 \text { mil } \\
\text { personas..." } \\
\text { "...se espera que un amplio número de compositores/as } \\
\text { de..." } \\
\text { - "Quien suscribe“ } \\
\text { • "Cada postulante deberá portar carpetas." } \\
\text { - "Cuando alguien lee las listas." } \\
\text { "La población..." }\end{array}$ \\
\hline
\end{tabular}

A further focus of the analysis grid is the presentation of potentially gender-related subject areas, such as family, hobbies/leisure time, profession, household and visual appearance. For instance, the frequency and way of presenting male and female characters in texts and illustrations and the extent to which patterns of behaviour, characteristics, actions etc. are gender-typed can be analysed. Furthermore, the question in which constellations the characters appear (e.g. same-sex or mixed-gender dyad, in a group) can be addressed. In addition, the location and positioning in which the characters appear may be of interest for the analysis.

To go beyond binary gender constructions, the analysis grid indicates the possibility of appointing male or female persons who cannot be clearly allocated (Bittner 2011).

In a further step, the results of both areas of analysis can then be compared with each other and similarities and differences can be pointed out. This will make it possible to find out how gender is represented from both linguistic and thematic perspectives and what attempts are made to question and break down stereotypes.

\section{Central Findings}

\section{ELE textbooks for first/second-year pupils}

\section{Language}

With a view to determine whether and how gender-sensitive language is used in textbooks, the analysis is based on the above-mentioned levels and dimensions.

Written language in textbooks is mainly evident in tasks and texts, therefore these aspects are considered to be a priority.

In the three analysed textbooks for the first and second year of learning there are different formulations of tasks, which are presented below in an exemplary manner:

\begin{tabular}{|c|c|c|}
\hline iArriba! 1 & Rutas para ti & ¡Vamos! ;Adelante! 2 \\
\hline 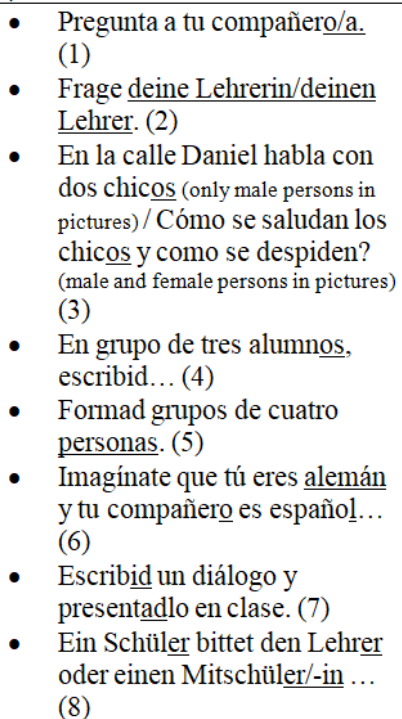 & $\begin{array}{ll}\text { - } & \text { Presenta a una compañera o } \\
\text { un compañero.... (9) } \\
\text { - } \quad \text { Formad grupos y presentaos } \\
\text { las personas. La profesora da } \\
\text { el ritmo. (10) } \\
\text { - } \text { Habla con tu pareja. (11) } \\
\text { - } \quad \text { Cómo es vuestro profesor de } \\
\text { español? (12) } \\
\text { - Cuántos años tienen tus } \\
\text { amigas o amigos? (13) } \\
\text { - } \text { Cada persona tiene que } \\
\text { presentar... (14) } \\
\text { - Discutid en pareja como } \\
\text { podéis explicar el horario a un } \\
\text { estudiante español. (15) } \\
\text { Prepárate para poder enseñar } \\
\text { las instalaciones y servicios } \\
\text { de tu instituto a una estudiante } \\
\text { española. (16) } \\
\text { Intenta adivinarla antes de } \\
\text { preguntar a tu profe. (17) }\end{array}$ & $\begin{array}{l}\text { - Preguntad a cinco } \\
\text { compañeros. (18) } \\
\text { - Tus amigos de Madrid te } \\
\text { visitan. (19) } \\
\text { - } \quad \text { Un alumno pregunta a dos } \\
\text { compañeros. (20) } \\
\text { - Comparad vuestras preguntas } \\
\text { con las de vuestro compañero. } \\
\text { (21) }\end{array}$ \\
\hline
\end{tabular}

It can be seen from the table that there are not only differences in the methods used to create gender equality in language by specifying and abstracting different genders, but also in their scope, consistency, and coherency.

For example, there are both integrated pair reference forms (1,8 (Mitschüler/-in)) and those that write both forms separately $(2,9,13)$, as well as collective names that include all genders $(5,10,11,14)$.

The generic masculine is used for different purposes, which partly leads to confusion, since, for example, in one picture with only male persons and in a directly following one with male and female persons, the term chicos is used (3) The generic masculine in the plural is also found in numerous other formulations $(4,18,19,20)$, but is only used 
consequently and coherently for this purpose in the textbook ;Vamos! ;Adelante! 2, which is why there is no form of gender specification or abstraction in the tasks.

Although it is common in Spanish to use the masculine third person plural for a group of male and female persons, a generic use is also found in the singular $(6,8,12,20,21)$.

As a counterexample to the generic masculine, the nouns in sentences 10 and 16 are feminised.

With the exception of the collective term personas, all other methods of gender specification and abstraction are binary and do not include any other/all genders.

Furthermore, pupils are often addressed directly by using concrete questions (13) or the imperative form (you, 2. pers. sng./pl.). Nevertheless, in this gender-neutral way of addressing the issue, there are formulations that are used generically $(6,12,21)$ and sometimes even arbitrarily $(15,16)$.

Another method of gender abstraction is the usage of profe as a short form of the noun profesor/a (17).

Both in tasks, but also in texts, the frequency and order in which male and female names are mentioned are relatively balanced (e.g. "Daniel y Sofia"; "María y Daniel").

The chosen names are names that can usually be clearly related to male or female persons (e.g. Lisa, Manfred, Tanja, Raúl, Paco, Isabel). Although this contributes to a lexical binary gender specification, unisex names (e.g. Andrea) to include all genders are only used one time in Rutas para ti.

If one looks at the composition of substantivistic personal reference forms, it is noticeable that in the area of family relations the collective terms familia and relaciones familiares are chosen as superordinate terms, but as is usual in Spanish language, the masculine form is used in the plural for (grand-)parents and uncle/aunt (los abuelos, los papás, los tíos).

Only the textbook Rutas para ti refrains from using generic plural forms and consistently differentiates between male and female gender in the singular forms (e.g. mi madre y mi padre; Teresa es la abuela y Ramón el abuelo... instead of Los abuelos Teresa y Ramón...).

Job titles are introduced in the lesson according to the respective gender presented and are not further specified.

In the vocabulary section, kinship relations and job titles are presented in the singular form and specified according to a binary gender understanding using integrated pair reference forms (el/la abuelo/a; el/la pilota) and separate words (el alumno/la alumna).

The preceding analysis results can also be transferred to the texts of the textbook and here once more it becomes evident, how differently the gender-sensitive language is dealt with.

Before analysing the individual gender-related topic areas, the following section provides an analysis of illustrations which helps to contextualise the following results.

Short analysis of illustrations

In general, it can be said that the number of male and female persons is well-balanced in all the three analysed textbooks. Most of the illustrations show groups of the same or mixed sex.

Looking more closely at the positioning of the persons in the pictures, it is noticeable that male persons are more often shown first (from left to right). It is also noticeable that in two of three textbooks persons are often positioned according to their male or female appearance (male persons on the left and female persons on the right). Moreover, male persons are more often positioned above women than vice versa.

With regard to the depicted places in the pictures, a less stereotypical attribution to gender can be seen. For example, both male and female persons are shown in the laboratory, library, kitchen, supermarket, at the airport or on the football field. Furthermore, only female persons are shown in the computer room or clothing shop, whereas only male persons are illustrated on the basketball court, in the stadium or handball arena.

Topic area "family/relationships"

Both in the illustrations and in the texts only traditional family structures are represented, which generally consist of four-person or multi-generational households. There is no evidence of patchwork families, single parents or same-sex partnerships. One of three textbooks introduces the topic area family about the kinship relations of Pablo Picasso. However, no reference is made to the fact that Pablo Picasso, for example, had children with different women. Having children with different men or women corresponds to current trends in family life and provides a way of referring to topics like divorced parents and patchwork families. In all textbooks analysed, relationships are exclusively related to heterosexual ones (¿Cómo se llama el novio de tu amiga?).

Topic area "(leisure) activities/sports/interests"

In this topic area, attempts are often made to avoid stereotypical attribution to gender. Male and female persons are shown together chatting, reading, learning, watching TV, doing sports (dancing, swimming, surfing, hiking), partying, buying food and cooking. Nevertheless, activities such as, playing/watching football and videogames or driving a car are attributed primarily to male persons, whereas activities such as, shopping and having dinner with the family are characterised as female.

In one of the analysed textbooks leisure activities are presented in the shape of a bar chart without any reference made to gender-related differences.

Topic area "visual appearance/clothes/colours" 
All persons are illustrated in a way that they can be related to masculinity or femininity, e.g. all female persons have long hair. Only one male person is shown with longer hair. This is further substantiated by the attribution of clothing and colours. In one of the three textbooks the differences between male and female persons are represented by a kind of comparison of clothing (trouser - dress/skirt) and colours (black/blue - pink/purple).

In the other two textbooks, the attribution of clothing and colours is less gender-stereotyped, e.g. male persons wear the colours red and rose. It is also striking that in one textbook, when describing the daily routine, a female person is shown alternately wearing a pink and blue blouse.

In some cases, articles of clothing are shown separated and not related to a particular person.

Nevertheless, female persons are mentioned significantly more often than male persons in the area of clothing. This can also be seen, for example, in the introduction to a woman's fashion blog gathering feedback on her outfit.

Topic area "world of work/profession"

Since this topic area is not dealt explicitly in the first volumes, only two examples can be referred to. In one of three analysed textbooks the mother works in the IT industry from home and the father is a pilot and rarely at home. In each lesson, letters are sent from the father to the family. To be considered stereotypical is the attribution of mobility to male persons. Another profession which is still explicitly mentioned is a saleswoman in a clothing store.

Topic area "household/kitchen"

In one of the analysed textbooks, two adolescents (male/female) are shown with their grandmother preparing a typical Spanish dish in the kitchen. In the other analysed textbooks only female persons are cooking or hoovering, which leads to the impression that a stereotypical classification tends to be made and primarily women are placed in this topic area.

Topic area "celebrities"

Famous people are depicted in all analysed textbooks. In some of them only a small selection of persons is present, in others there are up to 7 celebrities. In two of three analysed textbooks a balance between male and female persons can predominantly be observed. In one textbook not a single female celebrity is mentioned. As a rule, the persons shown are writers, actors, sportsperson or singers.

Topic area "characteristics"

The attribution of characteristics to male and female persons can be described as gender-neutral; both female and male persons are described as quiet, active, funny, kind, likeable, clever and pretty.

ELE textbooks for fourth-year pupils

Language

In accordance to the findings above, the analysed textbooks for the fourth year of learning also contain various methods for specifying and abstracting gender (integrated pair reference forms, collective names etc.) and ways of using the generic masculine. There is also the use of questions and imperative forms addressing directly the pupils. A new type of wording is using the personal pronoun ,we“" (En esta tarea vamos a hablar del teatro...).

In each task of the textbook Apúntate 4 there is differentiated consequently and coherently between both forms in the singular (integrated pair reference form). The generic masculine is only used in the plural. In contrast, all tasks of the other textbook are continuously formulated in the generic masculine in the singular and do not differentiate gender.

In the texts of both textbooks, there are various methods for differentiating gender, which are used inconsistently. In Gente Joven 4 for instance mentioning names in tasks is largely omitted. In texts, names often appear individually. In the other textbook almost exclusively, female names are mentioned before male names.

The chosen names are names that can usually be attributed clearly to a male or female person (e.g. Nuria, Hugo, Eva, Violeta, Pedro, Ana). Although, this contributes to a lexical binary gender specification, unisex names to include all genders are only mentioned two times in Apúntate 4 (Cris, Luca).

If one looks at the composition of substantivistic personal reference forms, it is noticeable that in the area of family relations the collective term familia is chosen as the superordinate term, but as is usual in Spanish language, the masculine form is used in the plural for (grand-)parents and uncle/aunt (los padres, los tíos). In this area no evidence of differentiation by gender can be identified.

All tasks of the other textbook are continuously formulated in the generic masculine in the singular and do not differentiate gender.

Job titles are specified by using integrated pair reference forms (un/a científico/a, un/a deportista).

In the vocabulary section, nouns and adjectives are presented in the singular form and specified according to a binary gender understanding using integrated pair reference forms (el/la creador/a; vago/a).

In line with the analysis of first/second-year textbooks, a brief analysis of illustrations precedes the main analysis.

Short analysis of illustrations

In general, it can be said that the number of male and female persons is well-balanced in both analysed textbooks. Most of the illustrations show groups of the same or mixed sex.

Looking more closely at the positioning of the persons in the pictures, it is noticeable that male persons are more often shown first (from left to right), but in contrast to the results from above, it is striking that in both textbooks persons are neither positioned according to their gender nor are male persons placed above female ones. 
With regard to the depicted places in the pictures, a less stereotypical attribution is found out. For instance, both men and women are shown at the market, on the football pitch, theatre, music and circus stage as well as on the skatepark, parkour park and at a demonstration for human rights. Only female persons are depicted in the laboratory and polling station, whereas only male persons are shown in the office and art studio.

Topic area "family/relationships"

Both in illustrations and in the texts only typical family structures are presented, which generally consist of fourperson households. As mentioned above, there is no evidence of patchwork families, single parents or same-sex partnerships in the textbooks. In one of the textbooks analysed, one person talks about having two mothers and thanks them on the occasion of Mother's Day. The reason for this remains unclear, for example, whether it is due to the person living in a patchwork family or being adopted into a foster family. The depiction of love relationships is limited exclusively to heterosexual partnerships.

Topic area "(leisure) activities/sports/interests"

In this topic area, attempts are often made to avoid gender-stereotypical attributions. Male and female persons are shown together playing theatre, instruments and football, doing sports (parkour, hiking), playing computer games, learning, singing, demonstrating, shopping and baking. Exclusively male persons are depicted in activities such as painting, caring for animals and cooking. Only female persons are shown when working in the lab or voting during an election.

In Gente Joven 4 male persons are interested in literature, photography, theatre, art and basketball, which corresponds to a broad and less stereotypical representation of potential fields of interest. In contrast, women's interests are limited to theatre, education science and social engagement in organisations.

In the other textbook, the areas of interest are presented in a more stereotypical way, especially for male persons. Their hobbies refer, for example, to sports such as parkour and football, computer games and computer science. Female persons are presented more neutrally related to their hobbies and interests, e.g. doing sports (parkour, football, skateboarding), as well as being a booktuber and creating music lists.

Topic area "appearance/clothes/colours"

All persons are depicted in such a way that they can be related to male or female stereotype, e.g. all female persons have long and male persons short hair. Only one male person has got longer hair and one female is wearing dreadlocks. Nevertheless, the selection of clothing and colours is less stereotypical. For example, women wear different colours (blue, white, green, rose), hoodies and jeans as well as skirts, dresses and high shoes, covering a variety of potential clothing styles. Both male and female persons are represented, for instance with caps, sportswear and rucksacks.

In Gente Joven 4, a dialogue between mother and daughter is used to discuss the daughter's dress style. The mother wishes her daughter to wear a skirt, like other girls at her age, which the daughter refuses to do. She insists on continuing to wear hoodies and jeans.

With reference to the above results, female persons are not mentioned significantly more often than male persons in the area of clothing.

\section{Topic area "world of work/profession"}

The world of work is dealt explicitly in both textbooks and numerous professions are mentioned. The following professions are assigned to gender in Gente Joven 4: singers, musicians, artists and designers. However, only male persons are depicted as actors, graffiti sprayers or office workers and only female persons are described as medical students, writers and laboratory assistants.

Furthermore, the situation of applying for a new job is presented exclusively in the context of a female person and her curriculum vitae.

This observation is confirmed by the representation of the professional world in the other textbook. Professions are described here with reference to a four-person family. The mother is a deputy director in a company, the father is a receptionist in a hotel, the son works in a bakery and the daughter is a pupil and works as a waitress in a restaurant during the holidays.

What is striking here is that a woman has achieved a higher academic degree and a higher professional position in direct comparison to her husband.

Furthermore, occupational mobility is attributed exclusively to female persons who return from a business trip, for example.

Topic area "household/kitchen"

In one of the analysed textbooks, two adolescents (male/female) are shown with their father cleaning the living room while he is cooking a meal. Adult women are not represented in both textbooks in this topic area. In contrast to the results from above, these examples show that male persons are increasingly placed in household or housework scenarios.

Topic area "celebrities"

Famous people are depicted in both textbooks. In one of them only a small selection of persons is given (2), in the other one there are up to 21 celebrities. In both textbooks the representation of female and male celebrities is rather imbalanced.

In addition, female celebrities are presented exclusively in the context of the professions "author" and "singer", while male celebrities are presented as athletes, writers and astronauts. 
An exception is the representation of well-known female and male painters from Latin America in Apúntate 4, which goes beyond the typical professions of famous persons in textbooks. When comparing these results, a greater identification potential for pupils can be assumed, since not only singers and athletes are presented.

Topic area "fundamental rights"

In Gente Joven 4 the topic of fundamental rights is dealt explicitly. People are shown here at demonstrations as well as elections. It is noticeable here that significantly more female persons are depicted. Furthermore, in the area of elections only female persons are represented.

Addressing the issue of gender

Gender is not explicitly addressed in any of the analysed textbooks. When first names are introduced in most textbooks, names are assigned to the individual sexes in the form of a table or by ticking a box (male/female).

In most textbooks only one name is presented at a time. However, there is one case in which a group of two persons (Manfred y Tanja) should be assigned to one biological sex. It remains unclear here whether both boxes should/may be ticked or whether, from a linguistic perspective, it is a matter of the generic masculine in the plural.

For such tasks and exercises it would be useful to add a third gender as well as unisex names in order to explicitly address the issue and question a binary gender understanding.

Further concrete gender issues in many of the textbooks examined are found in job advertisements. Although there are attempts to create equality in language, they are all based on a binary understanding of gender. Although all job advertisements in daily newspapers, on homepages etc., which pupils may also read, have referred to three genders $(\mathrm{m} / \mathrm{f} / \mathrm{d})$ for years, the advertisements in modern ELE textbooks contain only the reference $(\mathrm{m} / \mathrm{f})$.

\section{DISCUSSION AND IMPLICATIONS}

Referring to Bittner's (2011) and Benitt/Kurtz's (2016) analysis results (foreign language English textbooks) as well as Moser/Hannover/Becker's (2013) and Ott's (2017) gender-related textbook studies (German textbooks), the results of the present analysis show that ELE textbooks are gender-equitable on some dimensions, but they still contribute in a subtle way to the social construction of gender inequality.

Gender-sensitive language is used, but not consequently and coherently. There were often mixtures of genderequitable forms and the generic masculine - which is likely to lead recipients to interpret the generic masculine forms as referring exclusively to male characters.

Nevertheless, there are good examples of gender-sensitive language in recent ELE textbooks.

It was also found that despite increasing age and language levels, the language is not becoming more gendersensitive. The most differentiated and neutral linguistical approach to gender was shown in a textbook for the first year of learning.

With regard to the subject areas, however, it could be shown that these are presented less stereotypically in textbooks for higher learning years (e.g. activities/hobbies, professions, appearance), whereby role flexibility and balance are acknowledged.

Notwithstanding, the analysis clearly shows that the norm of binary genders in ELE textbooks is not questioned. A constructivist concept of gender encompasses much more than the representation of women and men or the power relations between women and men. An understanding of gender as a social construction implies that the binary division of people into female and male is socially produced by society (Bittner 2015).

In all ELE textbooks examined, gender is constructed as a binary category, mainly through the appearance of persons. The depictions leave little or no scope for gender attribution.

Attempts to break through stereotypes can be found in the depiction of profession, hobbies and interests and housework.

The assumption of natural bisexuality represented in the textbooks studied, and further the idea of a difference between women and men, is conceptually closely linked to the concept of heteronormativity (ibid.). In the ELE textbooks examined there are simply no gay, lesbian or bisexual people. All couples shown correspond to the heterosexual norm.

Even though textbooks are obliged to reflect diversity of social reality, the results show that gender studies and theories of gender as a social construction are largely ignored, so that the thematization of gender and LGBT in schools and the creation of a space for its reflection and negotiation depends strongly on the respective teachers, if gender is understood as a not always obvious but omnipresent phenomenon (Volkmann 2007).

Otherwise this simplification shows only a part of society, causes a lack of support and identification potential for each pupil and prevents the real learning of many pragmatic aspects of neutral and authentic interaction with people with an LGBT background.

This idea coincides with Cunningsworth (1995) when he emphasises that materials should pursue authenticity in order to question, stimulate and enrich the learner's critical skills and curiosity (p. 88).

Finally, it should be pointed out that all the results presented should always be assessed with reference to a wide range of requirements that textbooks must meet, because according to Linke (2012), it is not so much important whether a text or language material contains gender-inequitable forms or representations, but how the potential for problematisation and awareness is used in the classroom by teachers (p. 163). 
It is therefore important that teachers are able to assess textbooks from a gender perspective, identify weaknesses and use further materials to implement gender-reflective teaching and learning.

Teachers can use various evaluation instruments to assess gender representations in textbooks, e.g. Bias Evaluation Instrument of the Nova Scotia Department of Education (2001).

Moreover literature, film and image didactic approaches can be particularly suitable for promoting gender awareness. Literary texts, films and images act as cultural and audio-visual expressions that give learners new perspectives, which differ from their own experiences and ways of thinking.

The use of texts, films and pictures for the purpose of gender reflection also has the advantage that a (self-)reflective examination of the gender relations portrayed can take place on the basis of the depicted persons/figures and that personal references to the learners' lifeworld are made possible but not required (König 2015; Lewin 2015).

The success of such suggestions depends largely on the willingness of teachers to critically examine their own experiences and attitudes with respect to gender order. Only with the appropriate gender sensitivity are teachers able to think the subject through at the level of educational decisions, to open their eyes to the diversity of young people and to constantly reflect on their own teaching practice (Lewin 2015).

\section{REFERENCES}

[1] ¡Apúntate! 4. (2019). new edition. Berlin: Cornelsen.

[2] ¡Arriba! 1. (2015). 1st edition. Bamberg: C.C. Buchner.

[3] Babka, A., \& Posselt, G. (2016). Gender und Dekonstruktion: Begriffe und kommentierte Grundlagentexte der Gender- und Queer-Theorie. Wien: facultas.

[4] Bär, M. (2012). Der ,Virus der Hispanophilie‘ an Schulen in Deutschland. In W. Altmann et al. (Eds.), Historia hispánica - Su presencia y (re)presentación en Alemania (pp. 241-252). Berlin: Walter Frey.

[5] Barceló Morte, L. (2006). Los estereotipos en género en los manuales de ELE. Estudio de las representaciones de varones y mujeres en cuatro libros de texto publicados entre 2003-2004. Retrieved on October 19, 2020 from https://redined.mecd.gob.es/xmlui/bitstream/handle/11162/77970/00820103007546.pdf?sequence=1\&isAllowed=y.

[6] Bengoechea, M., \& Simón, J. (2010). Gender Identity in Words for Professional Titles in Textbooks. In R.M. Jiménez Catalán (Ed.), Gender perspectives on vocabulary in foreign and second languages (pp. 188-211). Basingstoke: Palgrave Macmillan.

[7] Benitt, N., \& Kurtz, J. (2016). Gender Representation in Selected EFL Textbooks - A Diachronic Perspetctive. In D. Elsner \& V. Lohe (Eds.), Gender and language learning (pp. 169-188). Tübingen: Narr Francke Attempto.

[8] Bittner, M. (2011). Geschlechterkonstruktionen und die Darstellung von Lesben, Schwulen, Bisexuellen, Trans* und Inter* (LSBTI) in Schulbüchern. Eine gleichstellungsorientierte Analyse. Frankfurt a.M.: GEW.

[9] Bittner, M. (2015). Die Ordnung der Geschlechter in Schulbüchern. Heteronormativität und Genderkonstruktionen in Englischund Biologiebüchern. In F. Schmidt et al. (Eds.), Selbstbestimmung und Anerkennung sexueller und geschlechtlicher Vielfalt. Lebenswirklichkeiten, Forschungsergebnisse und Bildungsbausteine (pp. 247-260). Wiesbaden: Springer VS.

[10] Consejo Nacional de la Cultura y las Artes. (2016). Guía De Lenguaje Inclusivo De Género. Retrieved on September 27 from https://www.cultura.gob.cl/wp-content/uploads/2017/01/guia-lenguaje-inclusivo-genero.pdf

[11] Cunningsworth, A. (1995). Choosing Your Coursebook. Oxford: Macmillan Heinemann.

[12] Decke-Cornill, H. \& Volkmann, V. (2007). Gender studies and foreign language teaching. Tübingen: Narr.

[13] Decke-Cornill, H. (2009). Doing and Undoing Gender im Klassenzimmer. Methodische Grundsätze und einige Anregungen. Praxis Fremdsprachenunterricht 6, 14-19.

[14] Der Fremdsprachliche Unterricht Englisch. (2015). Negotiating Gender. Hannover: Friedrich Verlag.

[15] Elsen, H. (2018). Gender in Lehrwerken. Feministische Studien 36(1), 178-187.

[16] Elsner, D. \& Lohe, V. (2016). Introduction to Teaching Gender in the EFL Classroom. In D. Elsner \& V. Lohe (Eds.), Gender and language learning (pp. 9-18). Tübingen: Narr Francke Attempto.

[17] Galiano Sierra, I. (1993). La mujer en los manuales de español para extranjeros. In S.M. Paydró et al. (Eds.), Actas del Tercer Congreso Nacional de ASELE (pp. 119-125). Málaga/Murcia: Universidad de Málaga.

[18] Garnham, A., Gabriel, U., Sarrasin, O., Gygax, P., \& Oakhill, J. (2012). Gender representation in language and grammatical cues: When beauticians, musicians and mechanics remain men. Discourse Processes 49, 481-500.

[19] Gente Joven 4 (2016). new edition. Stuttgart/Barcelona: Klett/Difusión.

[20] Grein, M. (2012). Geschlechterforschung und Fachdidaktik Französisch (mit Hinweisen auf Fachdidaktik Spanisch). In M. Kampshoff et al. (Eds.), Handbuch Geschlechterforschung und Fachdidaktik (pp. 169-183). Wiesbaden: Springer VS.

[21] Grünewald, A., \& Küster, L. (2017). Fachdidaktik Spanisch: das Handbuch für Theorie und Praxis. Stuttgart: Klett.

[22] Gutenberg, A. (2013). Gendering/Queering in the Language Classroom. Gender und Queer Studies als Herausforderung für das schulische Fremdsprachenlernen. In E. Kleinau et al. (Eds.), Gender in Bewegung: aktuelle Spannungsfelder der Gender und Queer Studies (pp. 107-120). Bielefeld: transcript.

[23] Hegarty, P., Watson, N., Fletcher, L., \& McQueen, G. (2011). When gentlemen are fi rst and ladies are last: Effects of gender stereotypes on the order of romantic partners' names. British Journal of Social Psychology 50, 21-35.

[24] Klieme, E. (2006). Zusammenfassung zentraler Ergebnisse der DESI-Studie. Retrieved on September 12 from http://www.dipf.de/de/forschung/projekte/pdf/biqua/DESI_Ausge waehlte_Ergebnisse.pdf.

[25] Koch, C. (2020). Einführung in die Fachdidaktik Spanisch. Berlin: Erich Schmidt Verlag.

[26] König, L. (2015). Teaching Gender Reflection! Theoretische Grundlagen und literaturdidaktische Unterrichtsbeispiele für einen genderreflektierten Englischunterricht. In J. Wedl \& A. Bartsch (Eds.), Teaching Gender? Zum reflektierten Umgang mit Geschlecht im Schulunterricht und in der Lehramtsausbildung (pp. 261-288). Bielefeld: transcript.

[27] König, L. (2018). Gender-Reflexion mit Literatur im Englischunterricht: fremdsprachendidaktische Theorie und Unterrichtsbeispiele. Wiesbaden: J.B. Metzler. 
[28] König, L., Lewin, S., \& Surkamp, C. (2016). What Does it Mean to Teach About Gender? In D. Elsner \& V. Lohe (Eds.), Gender and language learning (pp. 19-38). Tübingen: Narr Francke Attempto.

[29] König, L., Surkamp, C., \& Decke-Cornill, H. (2015). Negotiating Gender. Aushandlungs- und Reflexionsprozesse über Geschlechtervorstellungen im Fremdsprachenunterricht anstoßen. In L. König et al. (Eds.), Special issue: Negotiating Gender. Der Fremdsprachliche Unterricht Englisch 49(135), 2-8.

[30] Lewin, S. (2015). Mit Bildern das Thema Gender bearbeiten. Praxisanregungen für den Englisch- und Französischunterricht der Sekundarstufe II. In J. Wedl \& A. Bartsch (Eds.), Teaching Gender? Zum reflektierten Umgang mit Geschlecht im Schulunterricht und in der Lehramtsausbildung (pp. 289-312). Bielefeld: transcript.

[31] Linke, G. (2012). Geschlechterforschung und Fachdidaktik: Sprachdidaktik Englisch. In M. Kampshoff et al. (Eds.), Handbuch Geschlechterforschung und Fachdidaktik (pp. 155-168). Wiesbaden: Springer VS.

[32] Lüning, M., \& Vences, U. (2007). Mujeres de clase en clase: Materialien zur Gender-Orientierung im Spanischunterricht. Berlin: Walter Frey.

[33] Ministerio De Sanidad, Servicios Sociales e Igualdad. (2015). Guías Para El Uso No Sexista Del Lenguaje. Retrieved on September 22

from http://www.inmujer.gob.es/servRecursos/formacion/GuiasLengNoSexista/docs/Guiaslenguajenosexista_.pdf.

[34] Mittag, M. (2015). Geschlecht als leerer Signifikant: Gendersensible Didaktik im Fremdsprachenunterricht. In J. Wedl \& A. Bartsch (Eds.), Teaching Gender? Zum reflektierten Umgang mit Geschlecht im Schulunterricht und in der Lehramtsausbildung (pp. 251-260). Bielefeld: transcript.

[35] Morales-Vidal, E., \& Cassany, D. (2020). El mundo según los libros de texto: Análisis Crítico del Discurso aplicado a materiales de español LE/ L2. Journal of Spanish Language Teaching 7(1), 1-19.

[36] Moser, F., Hannover, B., Becker, J. (2013). Subtile und direkte Mechanismen der sozialen Konstruktion von Geschlecht in Schulbüchern. Vorstellung eines Kategoriensystems zur Analyse der Geschlechter(un)gerechtigkeit von Texten und Bildern. Gender. Zeitschrift für Geschlecht, Kultur und Gesellschaft 5(3), 77-93.

[37] Naciones Unidas. (n.s.). Lenguaje Inclusivo En Cuanto Al Género. Retrieved on September 20 from https://www.un.org/es/gender-inclusive-language/guidelines.shtml.

[38] Nova Scotia Department of Educaiton. (2001). Bias Evaluation Instrument. Retrieved on September 2 from http://www.avrsb.ca/sites/default/files/documents/RCH/bias_evalu ation_instrument.pdf.

[39] Nübling, D. \& Kotthoff, H. (2018). Genderlinguistik: eine Einführung in Sprache, Gespräch und Geschlecht. Tübingen: Narr Francke Attempto.

[40] Ott, C. (2017). Sprachlich vermittelte Geschlechterkonzepte - eine diskurslinguistische Untersuchung von Schulbüchern der Wilhelminischen Kaiserzeit bis zur Gegenwart. Berlin/Boston: De Gruyter.

[41] Praxis Fremdsprachenunterricht. (2009). Gender. München: Cornelsen.

[42] Robles Fernández, M. G. (2005). La mujer en los manuales de español como lengua extranjera: del estereotipo al personaje real e histórico, mujeres insignes, mujeres comunes, mujeres sin más. Retrieved on September 15 from http://www.mepsyd.es/redele/Biblioteca2006/GorettyRobles.shtml.

[43] Robles Fernández, M. G. (2007). Where are women in Spanish Second Language textbooks? What they do? Who they are? In J. Santaemilia et al. (Eds.), International Perspectives on Gender and Language (pp. 553-569). Valencia: Universitat de Valencia.

[44] Rutas para ti. (2012). 1st edition. Paderborn: Schöningh.

[45] de Santiago Guervós, J. (2009). La discriminación en los manuales de ELE: un período crítico. marcoELE 8, 1-9.

[46] Schmenk, B. (2002). Geschlechtsspezifisches Fremdsprachenlernen? - zur Konstruktion geschlechtstypischer Lerner- und Lernbilder in der Fremdsprachenforschung. Tübingen: Stauffenburg-Verlag.

[47] Schmenk, B. (2016). Geschlecht. In E. Burwitz-Melzer et al. (Eds.), Handbuch Fremdsprachenunterricht (pp. 254-256). Tübingen: A. Francke.

[48] Schmenk, B. (2019). Genderspezifisches Lernen und Lehren. In W. Hallet et al. (Eds.), Handbuch Fremdsprachendidaktik (pp. 269-273). Seelze: Klett-Kallmeyer.

[49] Schößler, F. (2008). Einführung in die Gender Studies. Berlin: Akademie-Verlag.

[50] Senatsverwaltung für Bildung, Jugend und Familie. (2015). Rahmenlehrplan - Moderne Fremdsprachen. Retrieved on September 05 from https://bildungsserver.berlinbrandenburg.de/fileadmin/bbb/unterricht/rahmenlehrplaene/Rahmenlehrplanprojekt/amtliche_Fassung/Teil_C_Mod_Fremdspra chen_2015_11_16_web.pdf.

[51] Statistisches Bundesamt. (2018). Schüler/-innen mit fremdsprachlichem Unterricht. Wiesbaden. Retrieved on August 28 from https://www.destatis.de/DE/Themen/Gesellschaft-Umwelt/Bildung-ForschungKultur/Schulen/Tabellen/allgemeinbildendeberuflicheschulen-fremdsprachl-unterricht.html.

[52] Sunderland, J. (2010). Theorizing Gender Perspectives in Foreign and Second Language Learning. In R.M. Jiménez Catalán (Ed.), Gender perspectives on vocabulary in foreign and second languages (pp. 1-22). Basingstoke: Palgrave Macmillan.

[53] ¡Vamos! ¡Adelante! 2. (2015). 1st edition. Stuttgart: Klett.

[54] Volkmann, L. (2007). Gender Studies and Literature Didactics. Research and Teaching - Worlds Apart? In H. Decke-Cornill \& L. Volkmann (Eds.), Gender Studies and Foreign Language Teaching (pp. 161-184). Tübingen: Narr.

Johanna Lea Korell is research assistant and $\mathrm{PhD}$ student at the Justus-Liebig-University (Giessen) since October 2018. Her research interest lies within the teaching and learning foreign languages (Spanish, French) in educational contexts, especially theoretical and empirical materials research and didactics of multilinguaism. 